\title{
KESTÄVÄ KEHITYS
}

\section{Mikä on korkeatasoiseen, kokonaisvaltaiseen ajatteluun pystyvien henkilöiden rooli?}

\author{
Tässä artikkelissa Jenneth Parker tarkastelee korkeatasoiseen, koko \\ naisvaltaiseen ja laaja-alaiseen ajatteluun kykenevien henkilöiden roolia \\ kestävään kehitykseen tähtäävässä koulutuksessa. Parker käyttää \\ termejä "generalist" ja "quality generalist", joiden vastineena käännöksessä \\ käytetään termejä "generalisti" ja "korkeatasoinen generalisti".
}

Sain virikkeen tämän artikkelin kirjoittamiseen osallistuttuani Meeting in Finland -seminaariin Environment - a Challenge för Adult Education (Vapaan Sivistystyön Yhteisjärjestö 1992). Erityisen valitettavina ilmiöinä pidettiin tuolloin lisääntyvää erikoistumista sekä tiedon vieraantumista arvokysymyksistä. Vaadittiin integroidumpaa lähestymistapaa ympäristökasvatukseen ja painotettiin generalistien kasvavaa tarvetta. Rion ympäristökokouksessa, joka pidettiin samanaikaisesti Suomen seminaarin kanssa, maailman valtiot hyväksyivät päätöslauselma [alkup. "agenda"] 21:n, johon sisältyy sitoumuksia kestävään kehitykseen tähtäävän koulutuksen aikaansaamiseksi. (Viite 1).

Suhteutan seuraavassa toisiinsa vaatimukset generalistien kouluttamisesta ja sitoutumisesta kestävään kehitykseen tähtäävään koulutukseen. Käsittelen myös muutamia niistä ongelmista, jotka sisältyvät kokonaisvaltaiseen, kestävään kehitykseen tähtäävän koulutusohjelman toteuttamiseen. Tarkoitukseni on kehittää kokonaisvaltaiseen koulutukseen soveltuva laatukriteeri sekä hahmotella eräänlainen vähimmäistavoiteohjelma niille, jotka haluavat edistää kestävään kehitykseen tähtäävää koulutusta. Tarkastelen muutamia generalistien toiminnassa tähän asti ilmenneitä heikkouksia ja ehdotan tapoja, joilla niitä voitaisiin välttää tai korjata. Esitän, että generalisteille välttämättömät taidot ja älyllinen etiikka ovat sovellettavissa kriittisen ajattelun koulukunnan periaatteista sekä yksinkertaisesta pragmatismista. Tarkasteluni pääpaino on muutoksissa, joita tarvitaan länsimaisiin koulutusmalleihin, mutta joillakin esiin tulevilla näkökohdilla on merkitystä myös laajemmalla kansainvälisellä tasolla.

\section{KOKONAISVALTAINEN AJATTELU JA KESTÄVÄÄN KEHITYKSEEN TÄHTÄÄVÄ KOULUTUS}

\section{Generalistinen näkökulma}

Risto Willamo Helsingin Yliopistosta toi vakuuttavasti esille nykyisen länsimaisen koulutuksen perusongelman. (Viite 2). Samanaikaisesti kun yhä vakuuttavampi todistusaineisto osoittaa meille ympäröivän maailman eri prosessien keskinäiset yhteydet ja riippuvuudet, on tietämyksemme tullut yhä eriytyneemmäksi ja erikoistuneemmaksi. Vaikka poikkitieteellistä tutkimusta esiintyykin, sitä käytetään useimmiten vain opiskelijoiden tutustuttamiseksi akateemiseen työskentelyyn, minkä jälkeen edessä on erikoistuminen. Korkean tason poikkitieteelliseen tutkimukseen voi olla hyvin vaikea osallistua, koska tuolla tasolla eri tieteenalojen tutkijoiden on usein mahdotonta kommunikoida keskenään.

Sirpaleinen koulutuksemme estää Willamon mukaan meitä muodostamasta eheää maailmankuvaa. Tätä on pidettävä erityisen vaarallisena nykyään, kun tarve kyetä hahmottamaan maailman ympäristötilanne kokonaisvaltaisesti on polttavampi kuin koskaan. 


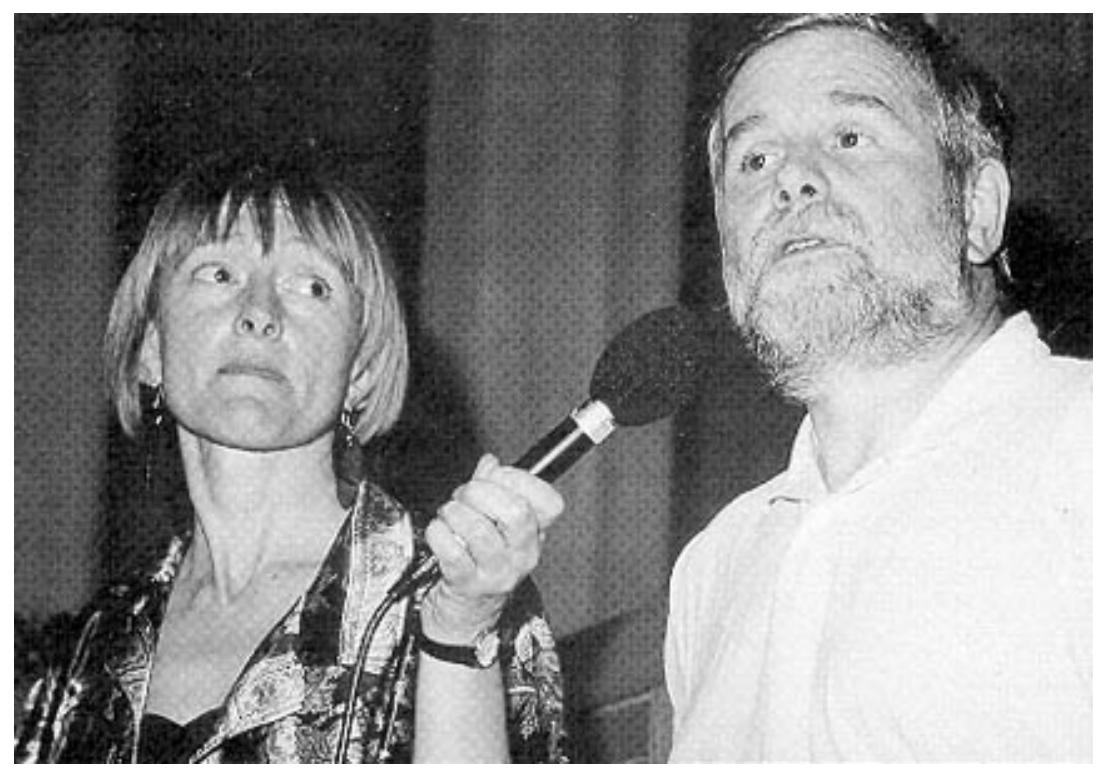

Jenneth Parker (vasemmalla keskustelukumppaninaan Illinois'n yliopiston, School of Art and Design, ekologisen suunnittelun laboratorion johtajan William Becker

Generalistinen argumentti ympäristökoulutuksen suhteen on se, että tietyllä erikoistumisen tasolla asiantuntijalle käy mahdottomaksi havaita oman alansa ulkopuolisia tarpeita ja lainalaisuuksia. Kuviossa 1 esitetään tästä voivan olla seurauksena se, että eri tieteenalojen toiminnan kohteina ovat erilaiset teoreettiset maailmat. Täten asiantuntija pyrkiessään ratkaisemaan ympäristöongelmaa saattaakin aiheuttaa uusia ongelmia, jotka ovat nähtävissä vain jonkin toisen tieteenalan kautta. Tästä seuraa myös vaatimus, että ympäristökoulutuksen on tultava aidosti poikkitieteelliseksi, ja että ympäristökysymykset tulisi sisällyttää kaikkiin tieteenaloihin.

Ehkä keskeisin generalistien argumenteista on kuitenkin se, että tarvitaan uusia poikkitieteellisiä viestintäkanavia. Poliittisella tasolla tämä tarve onkin tiedostettu, esimerkiksi EU:n piirissä (viite 3) ja parempaa koordinaatiota on vaadittu. Paremmin koordinoitujen toimintamallien luominen on kuitenkin eri tieteenaloilla vallitsevien toisistaan poikkeavien kulttuurien ja tietorakenteiden vuoksi yhäkin lähes mahdoton tehtävä. Kysymyksessä on siis todellakin hyvin konkreettinen ja kaikkia koskettava koulutuksen kriisi, johon on kiinnitettävä huomiota mitä pikimmin.

Kuvio 1: Osittunut tieto

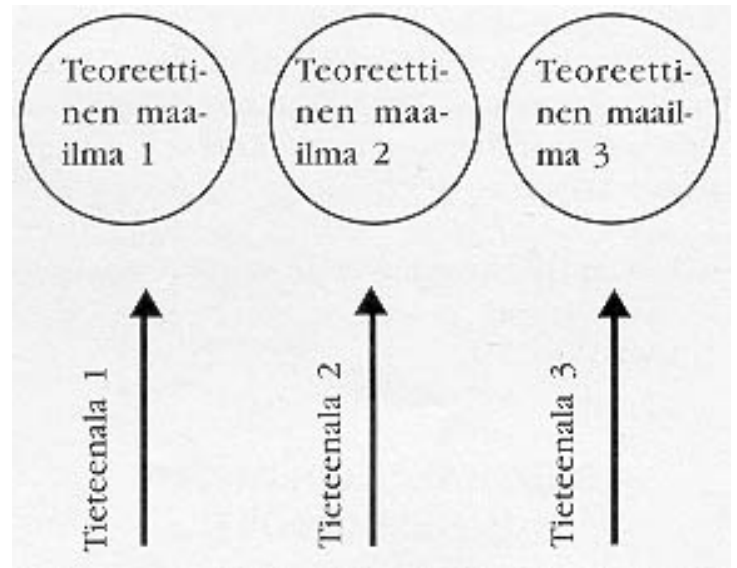

Tieteenalat 1,2 ja 3 sekä teoreettiset maailmat (maailmankuvat) 1, 2 ja 3 . Maailma [world system] on jaettu eri havaintoperspektiiveistä riippuviin erilaisiin teoreettisiin maailmankuviin. 


\section{Kestävään kehitykseen tähtäävä koulutus}

Kestävä elämäntapa voi jatkua rajattoman pitkälle tulevaisuuteen. Itse käsite on peräisin ekologiasta, ja sen alle voidaan periaatteessa yhdistää monia inhimillisen tiedon ja toiminnan alueita yhteisten kriteerien puitteissa. (Viite 4). Esimerkistä käy seuraava sitaatti Gro Harlem Brundtlandilta:

"Kestävällä elämäntavalla on monta ulottuvuutta. Ensiksikin se edellyttää köyhyyden ja puutteen eliminoimista. Toiseksi se edellyttää raaka-ainevarantojen säästämistä ja täydentämistä, joiden avulla vasta voidaan taata köyhyyden eliminoimisen pysyvyys. Kolmanneksi se edellyttää kehityksen käsitteen laajentamista siten, ettei siihen sisälly ainoastaan taloudellinen kasvu, vaan myös yhteiskunnallinen ja kulttuurillinen kehitys. Neljänneksi se edellyttää taloustieteen ja ekologian yhdistymistä kaikkien tasojen päätöksenteossa, mikä onkin kaikkein tärkein ulottuvuus." (Viite 5)

Kestävän elämäntavan etsiminen voidaan nähdä valtavana poikkitieteellisenä tutkimusohjelmana. (Viite 6). Kestävään elämäntapaan tähtäävän koulutuksen kehittämiseen täytyy sisällyttää nykyisten tiedon- ja tieteenalojen yleisarviointi. On myös arvioitava niiden käyttökelpoisuus sellaisten ongelmien ratkaisemisessa, jotka koskevat ihmisen pitkän tähtäimen selviytymisen ja kehittymisen mahdollisuuksia rajallisessa ekosysteemissä. Korkeatasoisten generalistien on kyettävä tämänkaltaisiin laajoihin kriittisiin arviointeihin, joiden pohjalta nykyinen järjestelmämme on voitava organisoida palvelemaan kasvatusta kestävään elämäntapaan. (Viite 7).

\section{GENERALISTIEN ROOLIT JA HEIKKOUDET}

\section{Nykyinen tilanne}

Voidaksemme luoda uudenlaista generalistista koulutusta on meidän aluksi tarkasteltava sitä, millainen rooli generalisteilla on tieto- ja tiedeyhteisössä. Ensiksi lyhyt katsaus nykytilanteeseen.

Monet generalistit ovat olleet nykyisenkaltaisen tietoyhteisön kannalta katsoen kelpaamattomia työllistettäviksi, joten ainoastaan määrätietoisimmat, kekseliäimmät tai yksinkertaisesti vain onnekkaimmat ovat voineet saavuttaa aseman sen piirissä. Monet kokonaisvaltaiseen ajatteluun vetoa tunteneet ovat joutuneet tukahduttamaan kiinnostuksensa rinnakkaisiin tieteenaloihin voidakseen hoitaa akateemista työtään. Toisista generalisteista taas on tullut popularisoivia intellektuelleja, jotka tarjoavat suurelle yleisölle kriittisiä kokonaisnäkemyksiä. Muutamat harvat ovat kyenneet myös yhdistämään tämänkaltaisen toiminnan akateemisen viran hoitoon. Kuitenkaan eivät edes menestyksekkäästi julkaisseet akateemisten virkojen haltijat yleensä kykene välttämään kohtalokseen muodostuvaa älyllistä syrjäyttämistä, sillä niin voimakasta on generalisteihin ja tieteen popularisoijiin kohdistuva ylenkatse.

Intellektuellien perinne - niiden, jotka ovat rohjenneet kritisoida tietoteollisuutta, sen rakenteita ja relevanssia - on ollut olemassa lähinnä humanistisissa tieteissä, muutamaa kunniakasta poikkeusta lukuunottamatta. Tiedemiesten keskuudessa hiljalleen heräävä tietoisuus siitä, että vastaavaa kritiikkiä tarvitaan myös muiden tieteenalojen piirissä, on ollut melko tuore ilmiö, jonka ajankohtaisuutta ympäristötieteiden kokonaisvaltainen luonne on korostanut.

\section{Mihin haluaisimme generalistien pystyvän?}

Voidaksemme tuottaa kestävään kehitykseen tähtäävää korkeatasoista kokonaisvaltaista koulutusta, on meidän palkattava generalisteja tiettyihin avainasemiin koulutuslaitoksissamme. Yrittämällä määritellä ne tehtävät, joita heiltä edellytettäisiin, voimme helpommin selvittää, millaisia taitoja ja tietoja heillä tulisi olla.

Samalla kun puhutaan korkeatasoisuudesta, on välttämätöntä nostaa esille kysymys generalistien asemasta ja statuksesta koko koulutusjärjestelmän puitteissa. On selvää, että korkeatasoista generalistista koulutusta ei 
voi olla olemassa, jollei niille henkilöille, jotka tiedeyhteisön puitteissa tekevät poikkitieteellisiin synteeseihin tähtäävää työtä, anneta suurta arvoa. Esitänkin, että meidän on luotava sekä tiedeyhteisön sisälle että sen ja muun maailman välisiin leikkauskohtiin monenlaisia uutta yhteistyötä ja yhteisymmärrystä edistäviä rooleja. (Viite 8). Joissakin tapauksissa tämä merkitsisi myös sellaisten henkilöiden aseman vahvistamista ja tunnustamista, jotka jo -osittain tai pääasiallisesti - suorittavat tällaisia tehtäviä.

Kuvio 2 kuvaa kolmea sellaista tietorakenteissa sijaitsevaa aluetta, joissa generalistien taitoja tarvitaan. Kukin alue edellyttää hiukan erilaisia vaikkakin toisilleen läheisiä taitoja sekä edellistä laaja-alaisempaa tietoa.

Kuvio 2: Generalistien tehtäväkentät

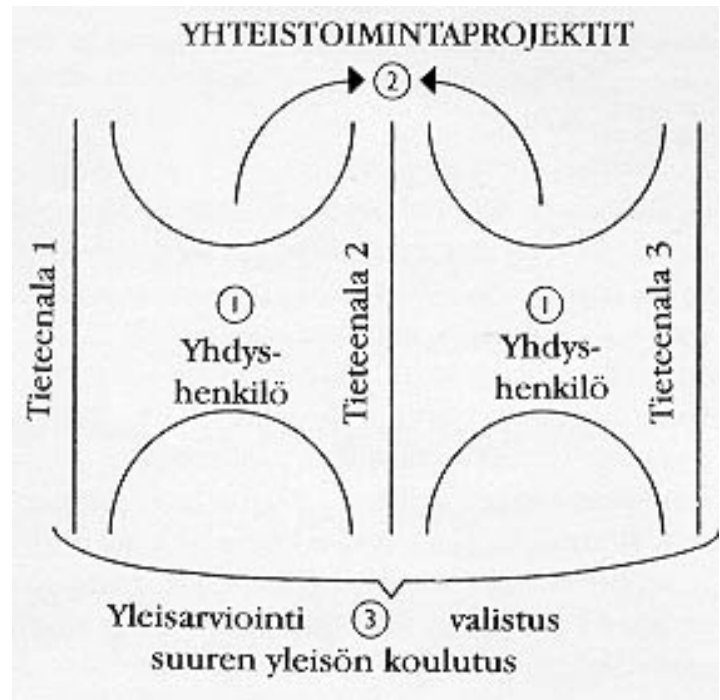

Tieteenalat 1,2 ja 3

Alue 1: Yhdyshenkilöt rinnakkaisten tieteenalojen välillä

Tehtävät:

- organisoida poikkitieteellisiä kursseja rinnakkaisten tieteenalojen arvoista, ympäristökysymyksistä ja julkisen päätöksenteon kohteena olevista asioista

- organisoida yhteisiä seminaariohjelmia

- organisoida erityistä henkilöstökoulutusta toisiaan lähellä olevien tieteenalojen ominaispiirteistä

- organisoida yhteistyökoulutusta

- paikantaa poikkitieteellisten tutkimusprojektien tarve ja saattaa niitä alulle

- olla erityisvastuussa poikkitieteellistä tutkimusta tekevistä opiskelijoista.

Alue 2: Yhteistoimintaprojektien avainhenkilöt

Tehtävät:

Kuten yllä, mutta yleisemmällä tasolla;

- organisoida strategioita joilla voidaan taata, että kaikki kestävän kehityksen kannalta oleelliset tutkimuskohteet saavat huomiota eri tutkimuslaitoksissa

- kehittää uutta tutkimusta eri tieteenalojen välisille kriittisille raja-alueille

- varmistaa, että kaikilla osastoilla ollaan selvillä kaikesta koko laitoksen puitteissa tapahtuvasta kestävää kehitystä koskevasta työstä

- organisoida erityisiä laaja-alaisia poikkitieteellisiä tapahtumia, esimerkiksi kutsumalla kokoon säännöllisesti tapaavan eri osastojen edustajista koostuvan työryhmän, jonka tehtävänä on arvioida tapahtuvaa edistystä.

Alue 3: Yleisarvioinnit ja kritiikki

Tämä alue ei kuulu minkään tietyn rakenteen piiriin, sillä näitä tehtäviä voidaan lähestyä monella eri tavalla. 
- Oleellista on jatkuvasti uudelleenarvioida, kuinka tehokkaasti tiede- ja tietoyhteisö on onnistunut edistämään ihmiskunnan tulevaisuuden turvaamista. Institutionaalisella tasolla tämän tulisi vähintäänkin merkitä kestävään kehitykseen tähtäävässä koulutuksessa tapahtuvan edistyksen säännöllistä raportointia.

- Tuloksena tulisi myös olla instituution valmius tukea laaja-alaiseen arviointiin tähtäävää tutkimusta, ja auttaa kehittämään sitä sekä luomaan sille parempia kriteerejä. Tämä on myös tärkeää, jotta instituutio saataisiin kantamaan vastuuta toiminnastaan suhteessa siihen yhteisöön, jota se palvelee.

- Tähän alueeseen kuuluu myös kestävään kehitykseen tähtäävän julkisen tiedottamisen kannalta olennaisten tekijöiden arviointi.

\section{Generalistien heikkoudet}

Pyrkiessämme luomaan uutta ja arvostetumpaa kokonaisvaltaista kulttuuria ympäristökysymyksissä, meidän on tärkeätä tarkastella myös sitä, millaisia tyypillisiä puutteita generalistien yrityksissä on ollut. Esimerkkejä näistä tavallisimmista puutteista löytyy valitettavan säännöllisesti "vihreän liikkeen" omista julkilausumista. (Viite 9).

Yleinen ongelma siinä generalistisessa toiminnassa, jota seuraavassa kritisoin on siinä, että se perustuu kuvion 3 mukaiseen itsekeskeisesti synteesejä luovaan malliin. Koska synteesien tuottaminen ja arviointi ovat olleet generalistien tehtäväkenttää, on usein tehty se implisiittinen olettamus, että he itse ovat arviointien ulkopuolella. Tämä on osittain johtunut generalistien älyllisestä eristyneisyydestä, ja on sikäli ollut myös väistämätöntä. Yleisten standardien puuttuminen on kuitenkin johtanut generalistien keskuudessa tapahtuvaan nahisteluun ja valtataisteluun. Se on ollut erityisen tuskallista siksi, että monet heistä sanoutuvat samojen hyvien päämäärien puolustajiksi.

Kuvio 3: Itsekeskeinen synteesi

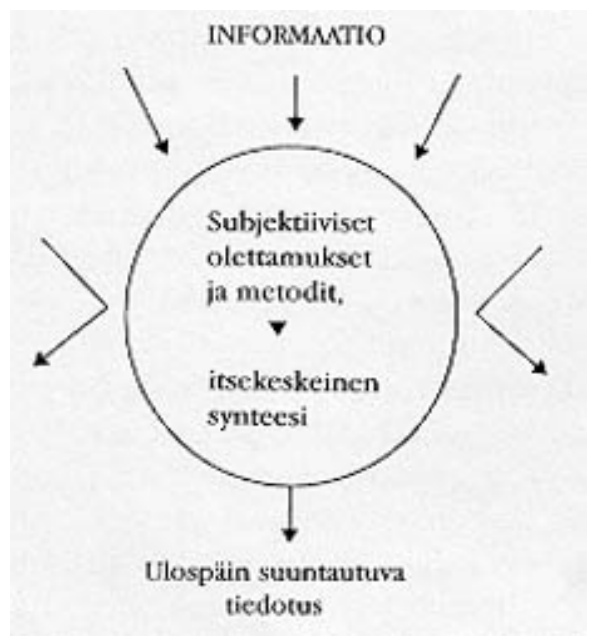

Seuraavassa muutamia generalistille tyypillisiä heikkouksia.

1. Hän olettaa, että kaikki ovat ilman muuta yhtä mieltä pääongelmista ilman, että niitä tarvitsisi perustella tai todistella.

2. Hän esittää tulkittua faktatietoa viittaamatta sen pohjana olevaan perustutkimukseen.

3. Hän sivuuttaa perustutkimuksen kokonaan eikä tutustu toisten generalistien samalta alalta tekemiin synteeseihin.

4. Hän syyllistyy osittaiseen synteesiin jättämällä pois yleisesti tärkeinä pidettyjä alueita selittämättä ja perustelematta laiminlyöntiään. 
5. Hän ei tuo selvästi julki omia lähtöoletuksiaan ja metodologiaansa.

6. Hän liittää toisiinsa asioita etukäteen omaksutun filosofian mukaisesti, valiten ja yhdistellen sinänsä irrallisia ja merkityksettömiä asioita ja päätyen näin kestämättömään rakennelmaan.

7. Hän esittää kokonaisnäkemyksen ottamatta esille vielä ratkaisemattomia kysymyksiä tai rinnakkaisia ongelma-alueita.

jotta kestävään kehitykseen tähtäävän koulutuksen luomisessa onnistuttaisiin, on generalistien tultava arvostetuksi osaksi tiedeyhteisöä sekä omaksuttava työlleen sellaiset standardit, jotka mahdollistavat heidän työnsä arvioinnin ja integroinnin. Näiden standardien tulisi myös auttaa poistamaan generalistien välisessä kommunikaatiossa vallitsevia haitallisia piirteitä. Tämä edellyttää kuvion 4 mukaista avoimempaa tiedonkulttuuria ja kriittisen tutkimuksen puitteissa tapahtuvaa yhteistyötä.

Korkeatasoinen generalismi on saavutettavissa pääasiassa kiinnittämällä huomiota kahteen keskeiseen älylliseen hyveeseen, nimittäin avoimuuteen ja vastuullisuuteen. Avoimuuteen päästään tuomalla oletukset, metodit ja lähteet selvästi esille, jolloin myös voidaan ottaa vastuu omista arvoarvostelmista. Näitä yleisiä periaatteita on kehitelty kirjoituksissa, jotka muodostavat ns. kriittisen ajattelun koulukunnan (viite 10), joka myös korostaa analyyttisten taitojen ja päätöksentekotaitojen hankkimisen tärkeyttä. Monimutkaisten ongelmien ratkaisutaidon keskeistä merkitystä on korostanut muunmuassa Stephen Trudgill (viite 11), Kuvio 4: Ammattitaitoinen synteesi joka sisällyttää ympäristöongelma-analyysiinsä myös konfliktien sovittelun.

\section{Pragmatismi}

Ympäristögeneralistin soveltaman pragmatismin tulee olla laadultaan strategista. Ensisijaisena tavoitteena tulisi olla saavuttaa niin paljon kuin kaikkien osapuolten suostumuksella ja nykyiseen tietämykseen perustuen on mahdollista. Tässä vaiheessa on myös tärkeää sisällyttää tavoitteisiin prosesseja, joiden kautta voidaan syventää asioiden ymmärtämistä ja siten pohjustaa suurempia muutoksia tulevaisuudessa.

Erimielisyyksiä siitä, mikä on kestävään kehitykseen tähtäävän koulutuksen kannalta keskeistä tulee aina olemaan, mutta tärkeätä olisi saavuttaa sellainen päätöksentekojärjestelmä, joka mahdollistaa sekä toiminnan että myös jatkuvan keskustelun ja uudelleenarvioinnin. Andrew Light on ympäristöpragmatismia formuloidessaan osuvasti kuvaillut vaaroja, jotka sisältyvät ympäristöliikkeen sisäisen keskustelun vaientamispyrkimyksiin. (Viite 12).

Tässä samassa hengessä haluan esittää ympäristökysymysten arvoihin nähden pragmaattista asennetta; niitä tulisi sisällyttää kaikkien oppialojen opetukseen, mutta valmiita reseptejä minkään tiettyjen arvojen korostamisesta ei tulisi antaa. Tässä vaiheessa olisi suureksi hyödyksi, jos näiden kysymysten merkitys voidaan hyväksyä ja jos eri tieteenaloilla vallitsevat arvot voitaisiin ottaa poikkitieteellisen tarkastelun kohteeksi.

\section{Generalisteilta vaadittavien ominaisuuksien suuntaviivoja}

Tarvittavat taustatiedot:

- kyky ymmärtää synteesin kohteena olevien tieteenalojen periaatteet; kyky ymmärtää niissä esitetyt teoriat ja arvioida teorioiden kattavuus ja laatu

- kyky ymmärtää suuren yleisön näkemykset, tiedon politiikka ja tiedon ongelmat

Taidot:

- yleiset arviointitaidot: kyky arvioida loogista johdonmukaisuutta, kyky löytää olennaiset asiat, harjaannusta ongelman ytimeen porautumisessa ja ratkaisua tukevien argumenttien löytämisessä 
- kyky luoda synteesejä: kyky vetää johtopäätöksiä ja tehdä ratkaisuja, kyky esittää saatavissa olevaan tietoon pohjautuvia perusteltuja johtopäätöksiä

- erimielisyyksien ratkaisutaidot ja neuvottelutaidot

- ryhmätyötaidot: Osallistuu ja rohkaisee muita osallistumaan uusiin yhteistyömuotoihin, joilla tuotetaan ja levitetään tietoa.

Kuvio 4: Ammattitaitoinen synteesi

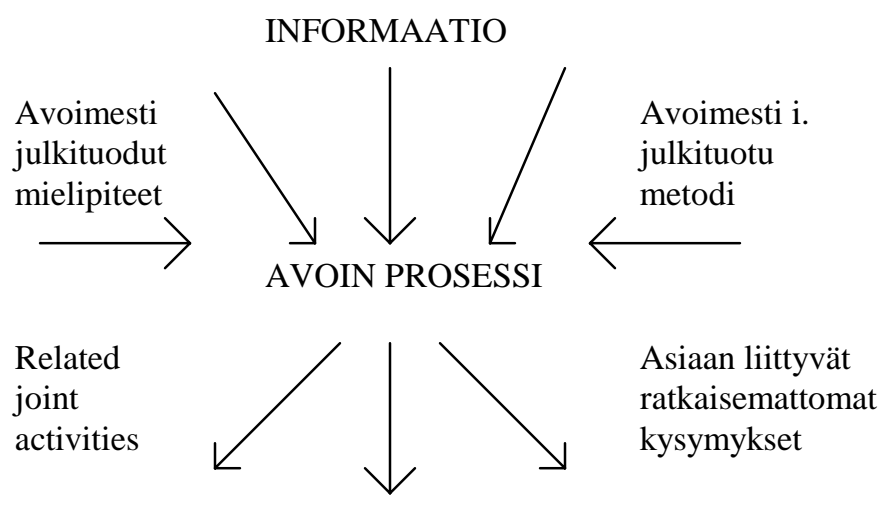

RAJALLISET JOHTOPÄÄTÖKSET

Eetos:

- älyllinen rehellisyys: Tehtyjen johtopäätösten rajoitukset tuodaan selvästi esille samoin kuin ne alueet, joilla tarvitaan lisätutkimusta ja joihin sisältyy vielä ratkaisemattomia ongelmia.

- yleinen tutkijanmoraali: On esitettävä selvät perustelut sille, mitä tutkimuksessa on huomioitu ja mitä ei, vastakkaisiin näkökantoihin on viitattava, mielipiteet on perusteltava. Relevantti faktatieto on sisällytettävä esitykseen tai siihen on viitattava.

- älyllisen itsekeskeisyyden välttäminen: pyrkimys eroon älyllisten nurkkakuntaisuuksien sotaisasta puolustamisesta, pyrkimys kohti avoimempaa ja yhteistyövaltaisempaa tutkimusta

\section{YHTEENVETO}

Kestävään kehitykseen tähtäävän, tehokkaan koulutuksen kehittäminen on meidän velvollisuutemme.

Generalistit ovat arvostelleet nykyisiä tieto- ja tiedeyhteisöjämme siitä, etteivät ne ole kyenneet tuottamaan ja levittämään sellaista tietoa, jota tarvitaan ihmiskunnan eloonjäämisen turvaamiseksi. (Viite 13). Asiantuntijoiden sirpaletieto ei useinkaan toimi silloin, kun sitä yritetään soveltaa maailmaan, joka ei kunnioita tieteenalojen välisiä rajalinjoja. Asiantuntijoiden erikoistuneet taidot puolestaan eivät tarjoa kokonaisvaltaiseen ongelmanratkaisuun tarvittavaa kognitiivisen synteesin kykyä. Eri tieteenaloille yhteisen lähestymistavan puute arvokysymyksissä merkitsee sitä, ettei meillä ole tarvittavia välineitä toimintaamme määräävien arvojen uudelleenarvioimiseksi kestävän kehityksen kannalta.

Generalistinen kritiikki on otettava huomioon, kun pyrimme kohti kestävään kehitykseen tähtäävää koulutusta. Toisaalta meidän on myös tunnustettava generalistien taidot sekä heidän roolinsa instituutioissamme ja kehitettävä niitä edelleen.

\section{VIITTEET}

1. 'Agenda 21', hankittavissa: The Centre For Our Cornmon Future, Talais Wilson, 52 Rue des Baquis, CH 1201 Geneva, Switzerland

2. Risto Willaino 1992. Kokonaisvaltaisuutta ympäristökasvatukseen. Artikkeli kiilassa Anneli Kajanto (toim.) 1992. Ympäristökasvatus. Vapaan sivistystyön vuosikirja. Aikuiskasvatuksen Tutkimusseura ja Kansanvalistusseura. 
Vastaava artikkeli myös kiilassa Outi Kitunen \& Tarja Parviainen (toim.) 1992. Ojasta allikkoon. Puheenvuoroja ympäristökoulutuksen itsestäänselvyyksistä. Suomen Ylioppilaskuntien Liitto.

3. Esimerkiksi "Green Paper on the Urban Environment" 1990. EC Commission 218, EC Publications Office L - 2980 Luxembourg.

4. "Sustainability..A Critical Standard". Konferenssiraportissa, Sustainable City European Forum. National Associationfor Urban Studies, Lewis Coben Urban Studies Centre, University of Bilgbton, 68, Grand Parade, Brigbton, BN2 $2 J Y$ England.

5. "Our Common Future". Raportti 1987. The World Commission on Environment and Development Oxford University Press

6 Interdisciplinary sustainability group, LEIF 2192

7. Wducation, Training andAwarenessfor a Sustainable Future" 1991. McCloskey et al. 7VE, 46, Charlotte street, London W7P ILX.

8. Tarvittaessa tietoa yleisestä ympätistökasvatuksesta: Jenneth Parker 1991. ”The Ettics ofInformed Consent and Citizen Environment Education". The International Forum for Biophilosophy Conference Proceedings 1992. LEB, Craenendonck 15, B - 3000 Leuven, Belgium.

9. Esimerkiksi Jonathan Porritt. "Comedown to earth you greens". The Guardian 7\&]992.

10. Lähdelista saatavissa: Centrefor Critical Thinking and Moral Critique, Sonoma State University, Rolmert Park, CA 94928 USA.

11. Stephen Trudgill 1990."Barriers to a Better Environment". Balhaven Press: London.

12. Andrew Light 1991. "Materialists, Ontologists and Environment Pragmatists". The MB proceedings, ks. viite 8.

13. Muiden lajien ja ekojärjestelmien säilyminen on kirjoittajan päämä̈̈rä. Se on ihmisen lajisäilymiselle välttämätön ehto. Ks. Bryan Norton. "Sustainability, Human Weyare and Ecosystem Health ". Environmental Values Voll No 2. The White Horse Press. Cambridge.

\section{YLEISI}

Jobn Pezzey. "Sustainability..An Interdisciplinary Guide". Environment Values Vol I No 4. The White Horse Press: Cambridge.

Shirley Ali Kahn. "Greening the Curriculum". Committee of Directors of Polytechnics. The Worldwide Fund for Nature, Panda House, Weybridge Park, Godalming, Surrey GU7 IXR. 